\section{Efficient Breeder Seed Production Utilizing Ethephon to Promote Floral and Fruit Abscission in Ornamental Chile Peppers}

\author{
Derek W. Barchenger, Danise L. Coon, and Paul W. Bosland ${ }^{1}$
}

AdDitional INDEX wORDs. Capsicum annuum, cross-pollination, ethylene, plant breeding, plant growth regulator

Summary. Controlled abscission of floral structures is an important horticultural technique that has many applications throughout the growing season. A novel use of chemical abscission in chile pepper (Capsicum annuum) is the removal of open flowers and fruit for the production of breeder seed. For efficiency of abscising flower buds, open flowers, and fruit of ornamental chile peppers, two foliar spray treatment levels, 1000 and $2000 \mathrm{ppm}$ ethephon were tested. Ornamental chile peppers were chosen because they are prolific flower and fruit producers, making removal of potentially cross-pollinated fruit and open flowers laborious. Flower bud and flower number were reduced with both 1000- and 2000-ppm ethephon treatments, while fruit number decreased only with 2000-ppm ethephon treatment. 'NuMex Easter' was more sensitive to ethephon treatment as compared with 'Chilly Chili' and 'Riot'. Ethephon had no negative impacts on end of the season growth index, mature fruit number, and seed number. We found ethephon can reduce numbers of flower buds, open flowers, and fruit with no long-term effect on mature fruit and seed number, making it a useful tool for the production of breeder seed in chile pepper breeding programs.

$\mathrm{C}$ hile peppers have extensive morphological diversity, especially for leaf and fruit color and shape as well as plant habit. This diversity has led to the development of chile pepper plants for ornamental applications (Stommel and Bosland, 2006). Ornamental chile peppers are extensively used as potted or bedding plants, and are popular in Europe and the United States (Bosland, 1999).

Although considered a selfpollinating crop, chile peppers can have outcrossing rates at sufficient levels to impede progress in breeding programs (Bosland, 1993; Tanksley, 1984). Bosland (1993) developed a simple and effective method of caging chile pepper plants for seed increase ensuring self-pollination for breeder seed, through the exclusion of pollinating insects. However, before caging can be implemented, all open flowers and possibly cross-pollinated fruit on the chile pepper plants must be removed. This is currently accomplished through laborious and timeconsuming hand removal, which is exacerbated in ornamental chile peppers because of their short stature and

Department of Plant and Environmental Sciences, New Mexico State University, P.O. Box 30003, MSC 3Q, Las Cruces, NM 88003

${ }^{1}$ Corresponding author. E-mail: pbosland@nmsu. edu. prolific flowering. To hasten the caging process, and more efficiently produce self-pollinated seed, a more efficient method of flower and fruit removal is needed and would be welcomed.

Ethephon (2-chloroethylphosphonic acid) is an ethylene-releasing compound and is labeled for many crops, including chile peppers. Ethephon has numerous horticultural applications, including limiting stem elongation, increasing lateral branching, and manipulating flowering date (Hayashi et al., 2001). In addition, ethephon has long been reported as a flower- and fruit-thinning agent on fruit crops such as citrus (Citrus sp.) and apple (Malus $\times$ domestica) (Davis et al., 2004). In olive (Olea europaea), ethephon treatments initiate abscission of flowers and peduncles of mature inflorescences (Weis et al., 1991).

Kahn et al. (1997) evaluated the effect of fall ethephon applications at concentrations of $0,1000,2000$, 3000 , and $4000 \mathrm{ppm}$ to control fruit abscission in paprika-type chile peppers. The authors recommended ethephon applications of 2000 to 3000 $\mathrm{ppm}$ during the growing season for the removal of immature fruit of paprika-type chile pepper. However, they stated that application time will vary due to genotype and environmental differences. In ornamental chile peppers, ethephon has been used to control plant height and increase lateral branching; however, this practice also delayed flowering and reduced fruit production (Khademi and Khosh-Khui, 1977). Santos et al. (2013) found that ethylene sensitivity was genotype specific in ornamental chile peppers.

Much of the work with ethephon on chile peppers is for increased uniformity in fruit maturity, facilitating cost-effective once-over mechanical harvest. Paprika-type chile peppers treated with ethephon before harvest have an increased ratio of red to green pods (Cantliffe and Goodwin, 1975). Ethephon has been shown to cause immature fruit and flower abscission in paprika and cayenne chile pepper in mid- to late-season applications (Kahn et al., 1997; Tripp and Wien, 1989; Uchanski and Blalock, 2013). There is no information on the effect of early season foliar applications of ethephon on chile peppers for flower and fruit abscission. Our objective was to determine the efficacy of early season ethephon foliar applications for floral and fruit abscission in ornamental chile peppers.

\section{Materials and methods}

For this study, three genetically diverse commercial ornamental chile peppers, 'Chilly Chili', 'Riot', and 'NuMex Easter' were evaluated. Seeds were sown in 96-cell plastic trays (T. O. Plastics, Clearwater, MN) filled with a commercial peatmossvermiculite soil mixture (RediEarth

\begin{tabular}{llll}
\hline $\begin{array}{l}\text { Units } \\
\text { To convert U.S. to SI, } \\
\text { multiply by }\end{array}$ & U.S. unit & SI unit & $\begin{array}{l}\text { To convert SI to U.S., } \\
\text { multiply by }\end{array}$ \\
\hline 29.5735 & $\mathrm{fl} \mathrm{oz}$ & $\mathrm{mL}$ & 0.0338 \\
0.3048 & $\mathrm{ft}$ & $\mathrm{m}$ & 3.2808 \\
3.7854 & gal & $\mathrm{L}$ & 0.2642 \\
2.54 & inch $(\mathrm{es})$ & $\mathrm{cm}$ & 0.3937 \\
1 & $\mathrm{ppm}$ & $\mathrm{mg} \cdot \mathrm{L}^{-1}$ & 1 \\
$\left({ }^{\circ} \mathrm{F}-32\right) \div 1.8$ & ${ }^{\circ} \mathrm{F}$ & ${ }^{\circ} \mathrm{C}$ & $\left({ }^{\circ} \mathrm{C} \times 1.8\right)+32$
\end{tabular}


Plug \& Seedling Mix; Sun Gro Horticulture, Bellevue, WA). Trays were placed on propagation pads to maintain root zone temperature at $28{ }^{\circ} \mathrm{C}$, and hand irrigated twice daily. Plants were grown in a climatecontrolled greenhouse maintained at 28 and $18 \pm 6{ }^{\circ} \mathrm{C}$ day and night temperatures, respectively, with a $12-\mathrm{h}$ photoperiod. Four weeks after sowing, plants were moved to a shade house for hardening.

Plants were grown at two locations in 2015, the Fabian Garcia Science Center in Las Cruces, NM [FGSC (lat. $32.16^{\circ} \mathrm{N}$, long. $106.46^{\circ} \mathrm{W}$; elevation $1186 \mathrm{~m})$ ] and the Leyendecker Plant Science Research Center in La Mesa, NM [LPSRC (lat. $32.11^{\circ} \mathrm{N}$, long. $106.44^{\circ} \mathrm{W}$; elevation $1174 \mathrm{~m})]$. Plants were transplanted at PSRC on 29 Apr. 2015 and at FGSC 1 week later. The plants were grown in a Glendale clay loam soil at LPSRC and in a Brazito very fine sandy loam soil at FGSC. Planting beds had 40 -inch centers, and plants were transplanted in a single line down the center of each bed, with in-row spacing of $\approx 10$ inches. All plots were furrow irrigated on $\approx 7$-d intervals at a rate of $\approx 3200 \mathrm{~L} \cdot \mathrm{min}^{-1}$ and managed as uniformly as possible according to best management practices (Bosland and Walker, 2004). The fields were periodically hand weeded throughout the growing season.

Three ethephon treatments were used for this study, 0 (water as control), 1000, and $2000 \mathrm{ppm}$. The ethephon label suggested 500 ppm for sensitive and $1000 \mathrm{ppm}$ for more ethylene-tolerant plant species, when used as a fruit thinner. In preliminary tests, a higher concentration was needed for complete floral and fruit removal, while maintaining reduced defoliation. In both locations, ethephon treatments were replicated five times and arranged in a randomized complete block design. Blocking was used to account for differences in furrow irrigation timing within each field. Treatment plots were $30 \mathrm{ft}$ long, with each cultivar planted in a $10-\mathrm{ft}$ strip within each plot. Measurements were taken only on the inner three plants of each cultivar, leaving two plants per cultivar as a buffer, to minimize border effects. Ethephon applications were made in the morning, once temperatures were greater than $18^{\circ} \mathrm{C}$, as ethephon is linked to plant growth activity and is therefore slower acting at temperatures lower than $15{ }^{\circ} \mathrm{C}$ and higher than $35{ }^{\circ} \mathrm{C}$ (Uchanski and Blalock, 2013). Applications were made while wind speed was still minimal, with a handpumped sprayer at a rate of $200 \mathrm{~mL} \cdot \mathrm{min}^{-1}$ from $\mathrm{l} \mathrm{ft}$ above the canopy. Plants were evenly sprayed, and applications resulted in complete leaf coverage, without runoff. Ethephon applications were made on 15 June 2015 at both locations.

Number of closed flower buds, fully opened flowers, and fruit were counted late in the afternoon before ethephon application and $8 \mathrm{~d}$ after ethephon application to determine closed flower bud, fully opened flower, and fruit drop. Number of mature fruit, seed number, and growth index $[\mathrm{GI}=$ plant height + (plant width $1+$ plant width $2 / 2) / 2$ ] was recorded at the end of the growing season to determine the efficacy of ethephon application on floral abscission within a season. The average seed number per fruit for each cultivar at each location was also determined. Data were analyzed by analysis of variance using $\mathrm{R}$ (version 3.1.2; $\mathrm{R}$ Foundation for Statistical Computing, Vienna, Austria). Tukey's honest significant difference test was used for mean separations $(\alpha=0.05)$.

\section{Results}

Data were analyzed by location, FGSC, and LPSRC, because significant differences for the numbers of flower buds, open flowers, fruit, mature fruit, seeds, and GI $(P<0.0001)$ occurred by location. At LPSRC, there were significant two-way interactions of treatment by day $(P<$ $0.0001)$ and cultivar by treatment $(P=0.018)$ for bud number, treatment by day $(P<0.0001)$ for flower number, and treatment by day $(P<$ 0.0001 ) for fruit number. For bud and flower number at FGSC, we observed significant two-way interactions of treatment by day $(P<0.0001$ and $P<0.0001$, respectively) and day by cultivar $(P=0.034$ and $P=0.003$, respectively) and the significant threeway interaction of treatment by day by cultivar $(P=0.001)$ for fruit number. The significant two-way interaction of treatment by cultivar occurred for GI at FGSC $(P=0.038)$ and LPSRC $(P=0.030)$.
At LPSRC, flower bud and flower number for the 0 -ppm treatment did not differ from 0 to $8 \mathrm{~d}$ for 'Chilly Chili', 'NuMex Easter', and 'Riot' (Fig. 1). However, fruit number increased from 0 to $8 \mathrm{~d}$ for the 0-ppm treatment at LPSRC for 'Chilly Chili', 'NuMex Easter', and 'Riot' (Fig. 1). Conversely, bud number decreased from 0 to $8 \mathrm{~d}$ at LPSRC for the 1000- and 2000-ppm ethephon treatment, with 2000 ppm resulting in fewer buds, for 'Chilly Chili', 'NuMex Easter', and 'Riot' (Fig. 1). Similarly, flower number also decreased from days 0 to 8 for 1000- and 2000-ppm ethephon treatment for 'Chilly Chili', 'NuMex Easter', and 'Riot' at LPSRC (Fig. 1). Interestingly, fruit number at LPSRC was largely unaffected by 1000-ppm ethephon treatment and remained relatively constant from 0 to $8 \mathrm{~d}$ for 'Chilly Chili', 'NuMex Easter', and 'Riot' (Fig. 1). However, 2000 ppm resulted in decreased fruit number from days 0 to 8 for 'Chilly Chili' and 'NuMex Easter', but not for 'Riot' at LPSRC (Fig. 1).

At FGSC, flower bud number decreased from days 0 to 8 for the control (0-ppm treated) 'Chilly Chili', 'NuMex Easter', and 'Riot' (Fig. 2). Flower number increased from 0 to $8 \mathrm{~d}$ at FGSC for 0-ppm-treated 'Chilly Chili' and 'NuMex Easter', but was not different for 'Riot' (Fig. 2). Similarly, fruit number increased from 0 to $8 \mathrm{~d}$ for 0 -ppm-treated 'Chilly Chili', 'NuMex Easter', and 'Riot' at FGSC (Fig. 2). As expected, flower bud number at FGSC decreased from days 0 to 8 for 1000- and 2000-ppmtreated 'Chilly Chili', 'NuMex Easter', and 'Riot' (Fig. 2). Likewise, flower number decreased from days 0 to 8 for the 1000- and 2000-ppm-treated 'Chilly Chili', 'NuMex Easter', and 'Riot' at FGSC (Fig. 2). Surprisingly, fruit number increased in 'Chilly Chili' at FGSC from days 0 to 8 for 1000 ppm treatment and did not differ for the 2000-ppm treatment (Fig. 2). Similar to those grown at LPSRC, fruit number did not differ from days 0 to 8 for the 1000-ppm-treated 'NuMex Easter' and 'Riot' at FGSC (Fig. 2). However, 2000-ppm treatment resulted in decreased fruit number from days 0 to 8 for ' $N u M e x$ Easter' and 'Riot' at FGSC (Fig. 2).

Significant differences in GI occurred; however, they were generally 


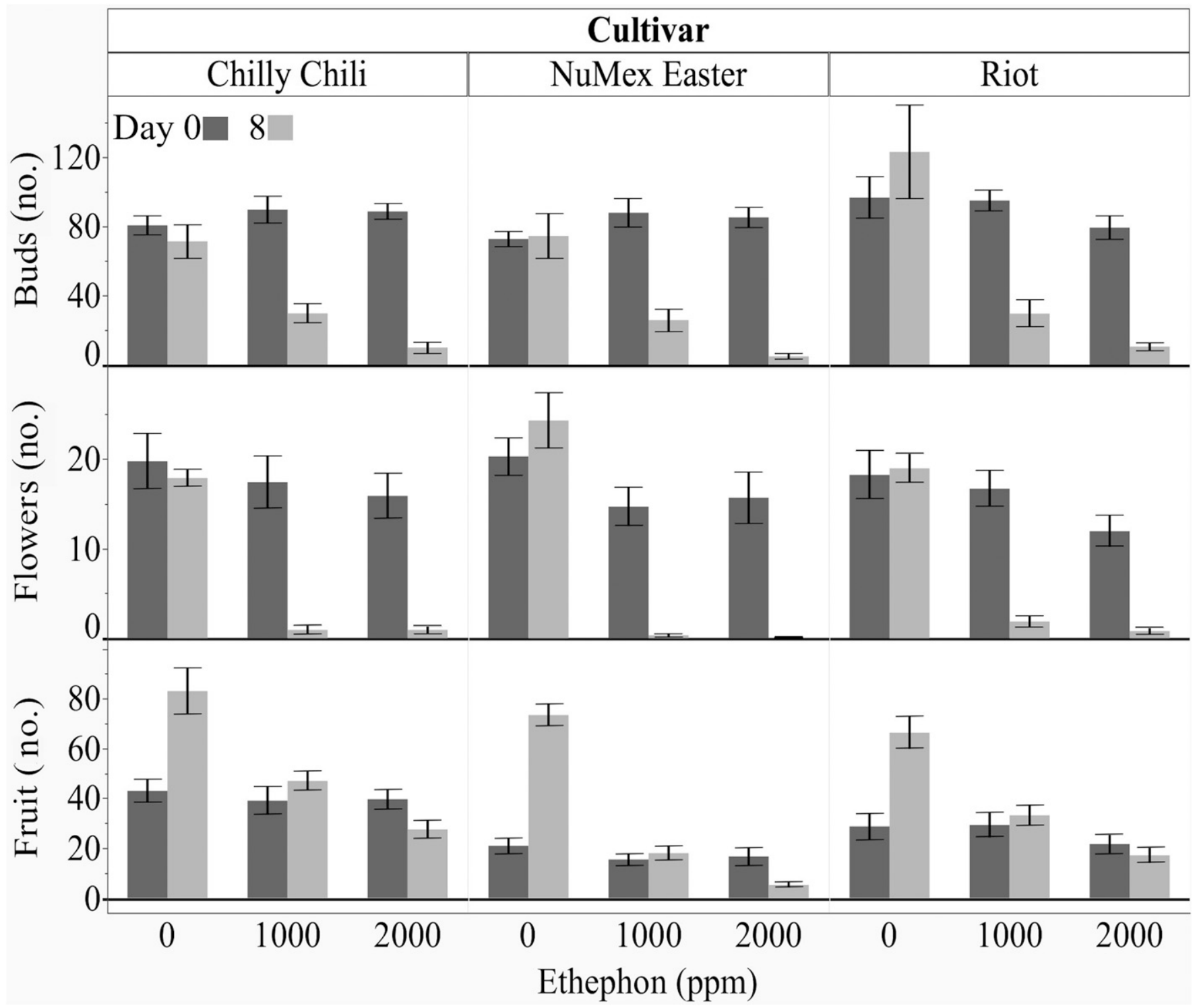

Fig. 1. Number of flower buds, open flowers, and fruit at 0 and $8 \mathrm{~d}$ after ethephon treatment for ornamental chile peppers grown at Leyendecker Plant Science Research Center (La Mesa, NM) in 2015. Each SE bar was constructed using 1 SE from the mean; 1 $\mathrm{ppm}=1 \mathrm{mg} \cdot \mathrm{L}^{-1}$.

minimal. At FGSC, the 2000-ppmtreated 'Chilly Chili' had the greatest GI, although not different from 0 and 1000-ppm-treated 'Chilly Chili' and 1000- and 2000-ppm-treated 'Riot', and 1000- and 2000-ppmtreated 'NuMex Easter' had the lowest GI (Table 1). Within each treatment at FGSC, 'NuMex Easter' generally had the lowest GI, while 'Chilly Chili' and 'Riot' generally did not differ (Table 1). At LPSRC, for 0 - and 1000-ppm treatments, 'Chilly Chili' had lower GI than 'NuMex Easter' and 'Riot', which did not differ for GI (Table 1). Conversely, for 2000-ppm treatment at LPSRC, 'Riot' had the lowest GI, while the GI for 'Chilly Chili' and NuMex Easter' did not differ (Table 1). Although means separation not reported across location, it was observed that GI was generally higher at LPSRC, as compared with FGSC (Table 1).

At the end of the season at both FGSC and LPSRC, mature fruit number and seed number did not differ between cultivars or ethephon treatments (Table 1). Mature fruit number and seed number were observed to be generally higher at LPSRC as compared with FGSC. At FGSC, mature fruit number ranged from 50 fruit ( 0 -ppm-treated 'Riot') to 91 fruit (2000-ppm-treated 'Chilly
Chili') and seed number ranged from 2288 (1000-ppm-treated 'NuMex Easter') to 5038 (2000-ppm-treated 'Chilly Chili') (Table 1). At LPSRC, mature fruit number ranged from 196 (0-ppm-treated 'Chilly Chili') to 370 (2000-ppm-treated 'NuMex Easter') and seed number ranged from 10,882 (0-ppm-treated 'Chilly Chili') to 16,702 (2000-ppm-treated 'Chilly Chili') (Table 1).

\section{Discussion}

Flower bud number, flower number, fruit number, GI, mature fruit number, and seed number for all three cultivars varied by location. The difference in location could have 


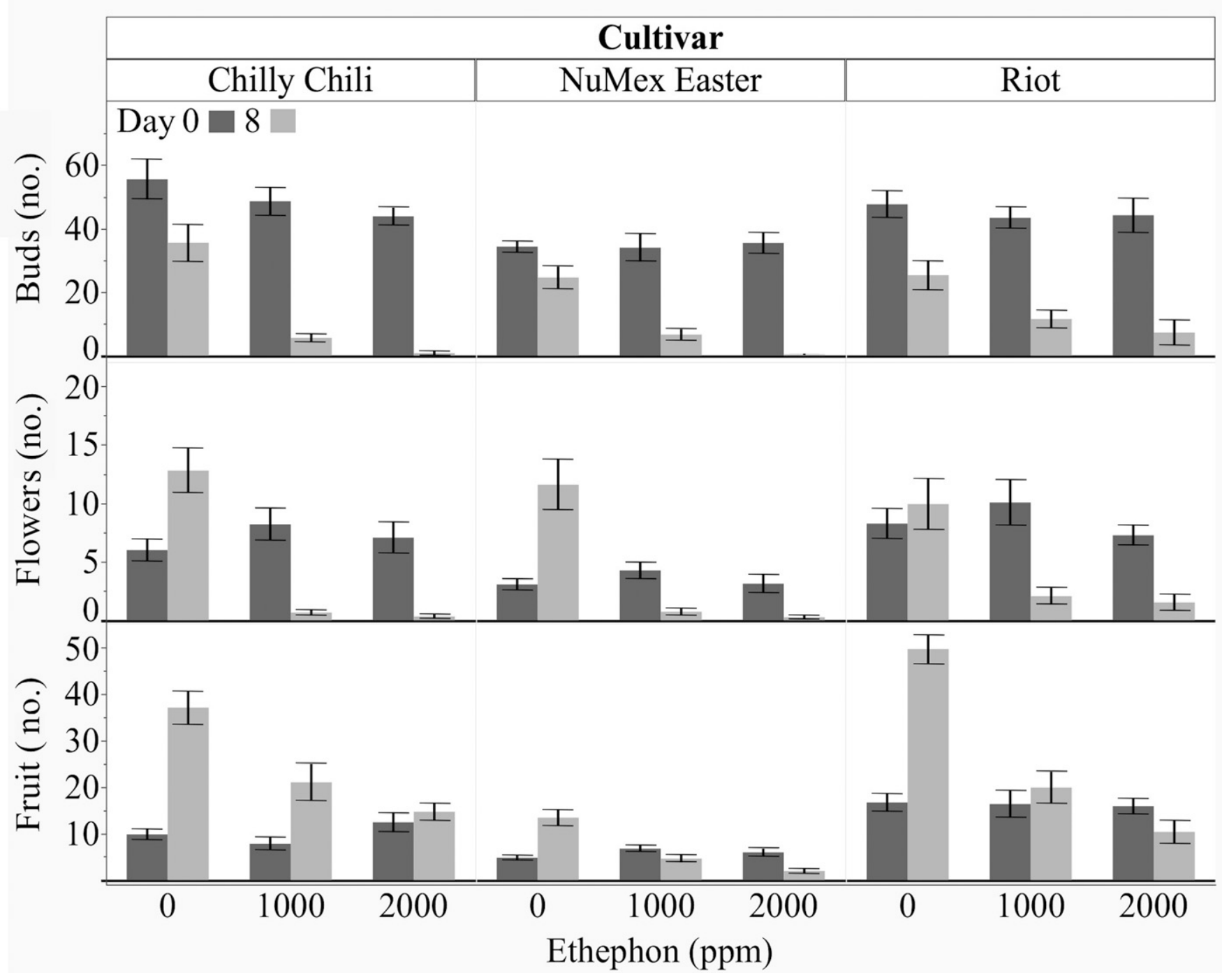

Fig. 2. Number of flower buds, open flowers, and fruit at 0 and $8 \mathrm{~d}$ after ethephon treatment for ornamental chile peppers grown at Fabian Garcia Science Center (Las Cruces, NM) in 2015. Each sE bar was constructed using 1 se from the mean; $1 \mathrm{ppm}=1 \mathrm{mg} \cdot \mathrm{L}^{-1}$.

been due to differences in soil type, planting date, and farm management practices. Growing environment, or location, has previously been shown to influence the effect of ethephon application in chile pepper (Uchanski and Blalock, 2013). Within each location, the ethephon treatment was the major contributor to variation for flower bud and flower number, while cultivar effect at FGSC and ethephon treatment at LPSRC were the major sources of variation for fruit number. This supports previous findings that an increased ethephon rate results in increased abscission in chile pepper (Kahn et al., 1997) and that ethylene sensitivity in ornamental chile pepper is genotype specific (Santos et al., 2013).

Abscission occurs at a thin layer of differentiated cells, known as the abscission zone that enlarges in response to ethylene (Rosales et al., 2009). Controlled abscission is an important horticultural technique used to thin immature fruit early in the season to increase mature fruit size, quality, and uniformity (Davis et al., 2004; Weis et al., 1991) as well as decrease number of immature fruit at harvest (Cantliffe and Goodwin, 1975; Kahn et al., 1997; Uchanski and Blalock, 2013). We were successful in using the ethylene-releasing capacity of ethephon to promote floral and fruit abscission at the abscission zone (Fig. 3), resulting in reduced flower bud, flower, and fruit numbers (Figs. 1, 2, and 4). Increasing ethephon rates resulted in increased flower bud, flower, and fruit drop (Figs. 1 and 2), supporting the findings of Kahn et al. (1997). It was observed that after day 8 of treatment, the abscission zone was darkened (Fig. 3); illustrating what is likely cell suberization or lignification as the result of flower bud, flower, and fruit drop. Suberization or lignification is a major part of the wound healing process of plants (Wang et al., 2013), and ethylene has been shown to play a critical role in suberization due to wounding (Lulai and Suttle, 2004).

At LPSRC, 2000-ppm ethephon treatment resulted in reduced fruit number in 'NuMex Easter' and 'Chilly Chili', but not 'Riot' (Figs. I and 4). Conversely, at FGSC 2000 ppm ethephon resulted in reduced fruit number in 'NuMex Easter' and 'Riot', but not 'Chilly Chili' (Fig. 2). 
Table 1. End of season growth index (GI), mature fruit, and seeds of three ornamental chile pepper cultivars treated with ethephon and grown at Fabian Garcia Science Center (Las Cruces, NM) and Leyendecker Plant Science Research Center (La Mesa, NM) in 2015.

\begin{tabular}{|c|c|c|c|c|}
\hline Treatment $(\mathrm{ppm})^{\mathrm{z}}$ & Cultivar & $\mathbf{G I}^{\mathbf{y}}$ & Mature fruit (no.) & Seeds (no.) \\
\hline \multicolumn{5}{|c|}{ Fabian Garcia Science Center } \\
\hline \multirow[t]{3}{*}{0} & Chilly Chili & $30.8 \mathrm{ab}^{\mathrm{x}}$ & 59.2 & $3,295.4$ \\
\hline & NuMex Easter & $25.0 \mathrm{de}$ & 67.1 & $2,538.8$ \\
\hline & Riot & $28.9 \mathrm{bcd}$ & 50.3 & $2,868.2$ \\
\hline \multirow[t]{3}{*}{1,000} & Chilly Chili & $31.3 \mathrm{ab}$ & 80.3 & $4,471.1$ \\
\hline & NuMex Easter & 26.0 cde & 53.2 & $2,288.3$ \\
\hline & Riot & $29.5 \mathrm{abc}$ & 64.1 & $3,655.9$ \\
\hline \multirow[t]{4}{*}{2,000} & Chilly Chili & $33.2 \mathrm{a}$ & 90.5 & $5,037.6$ \\
\hline & NuMex Easter & $24.2 \mathrm{e}$ & 67.1 & $2,886.2$ \\
\hline & Riot & $30.4 \mathrm{ab}$ & 67.0 & $3,821.1$ \\
\hline & & $P=0.038$ & $\mathrm{NS}^{\mathrm{w}}$ & NS \\
\hline \multicolumn{5}{|c|}{ Leyendecker Plant Science Research Center } \\
\hline \multirow[t]{3}{*}{0} & Chilly Chili & $42.5 \mathrm{~b}$ & 195.5 & $10,881.9$ \\
\hline & NuMex Easter & $45.2 \mathrm{ab}$ & 314.6 & $13,528.5$ \\
\hline & Riot & $47.5 \mathrm{ab}$ & 200.4 & $11,425.1$ \\
\hline \multirow[t]{3}{*}{1,000} & Chilly Chili & $48.1 \mathrm{ab}$ & 273.2 & $15,207.1$ \\
\hline & NuMex Easter & $49.1 \mathrm{a}$ & 320.8 & $13,793.8$ \\
\hline & Riot & $47.0 \mathrm{ab}$ & 262.7 & $14,971.8$ \\
\hline \multirow[t]{4}{*}{2,000} & Chilly Chili & $50.0 \mathrm{a}$ & 300.0 & $16,702.2$ \\
\hline & NuMex Easter & $48.8 \mathrm{a}$ & 369.8 & $15,900.2$ \\
\hline & Riot & $46.6 \mathrm{ab}$ & 253.5 & $14,447.4$ \\
\hline & & $P=0.030$ & NS & NS \\
\hline
\end{tabular}

${ }^{2} 1 \mathrm{ppm}=1 \mathrm{mg} \cdot \mathrm{L}^{-1}$

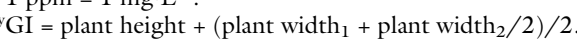

${ }^{x}$ Means within a column and location followed by the same letter do not significantly differ at $\alpha=0.05$ using Tukey's honest significant difference.

${ }^{\mathrm{w}} \mathrm{NS}=$ not significantly determined by an analysis of variance $\mathrm{F}$ test

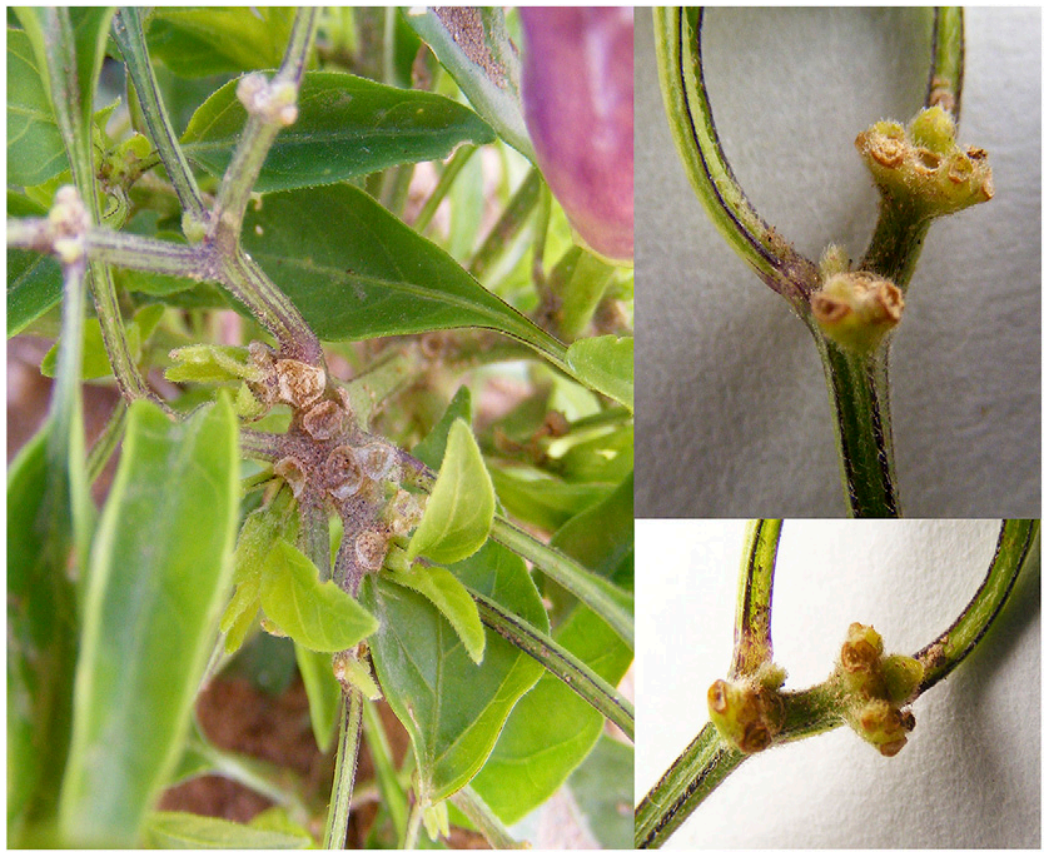

Fig. 3. Floral abscission zone browning, likely caused by cell suberization or lignification, of the chile pepper cultivar NuMex Easter grown at Fabian Garcia Science Center (Las Cruces, NM) 8 d after 2000-ppm ethephon treatment illustrating observed flower bud, flower, and fruit drop; 1 ppm = $1 \mathrm{mg} \cdot \mathrm{L}^{-1}$.
This illustrates a genotype by environment interaction, indicating the importance for multilocation evaluations for ethephon application. As breeding programs will likely be conducting seed increases for multiple genotypes within each season, this finding also demonstrates the importance of multigenotype evaluation for ethephon application.

At both locations, flower buds and open flowers were more sensitive to ethephon treatment than fruit. Flower buds and open flowers of all three cultivars significantly decreased with the lower ethephon rate (1000 $\mathrm{ppm}$ ) at both locations. This was noteworthy because flower and fruit removal is most important, as they have the greatest chance being crosspollinated compared with closed flower buds (Bosland, 1993). To increase the amount of fruit drop, increasing ethephon rates may be an option. However, this had the potential to result in excessive leaf abscission (Kahn et al., 1997), which may limit plant vigor throughout the season. Alternatively, ethephon could be applied earlier in the season, before fruit set, to remove the open flowers.

The major contributor of variation in GI was cultivar. This was especially true at FGSC, with the 0-, 1000-, and 2000-ppm-treated 'Chilly Chili' not being different and having among the highest GI of those evaluated. This was interesting, as ethephon has been shown to reduce height in other ornamental plants, such as poinsettia (Euphorbia pulcherrima) (Sun et al., 2011). Ethephon treatment had no effect on end of season mature fruit number and seed number for any of the cultivars. Likely due to application time (early season vs. late season), these findings differ from Krajayklang et al. (1999), who found that ethephon results in decreased yield in chile pepper.

In conclusion, flower number was reduced with 1000- and 2000ppm ethephon treatments, and fruit number reduced with 2000-ppm ethephon treatment. Although ethephon sensitivity was cultivar specific, a reduction in numbers of flower buds, open flowers, and fruit were observed in all cultivars. The response of ornamental chile peppers to ethephon was not consistent across environments, suggesting that soil type and farm management strategies 


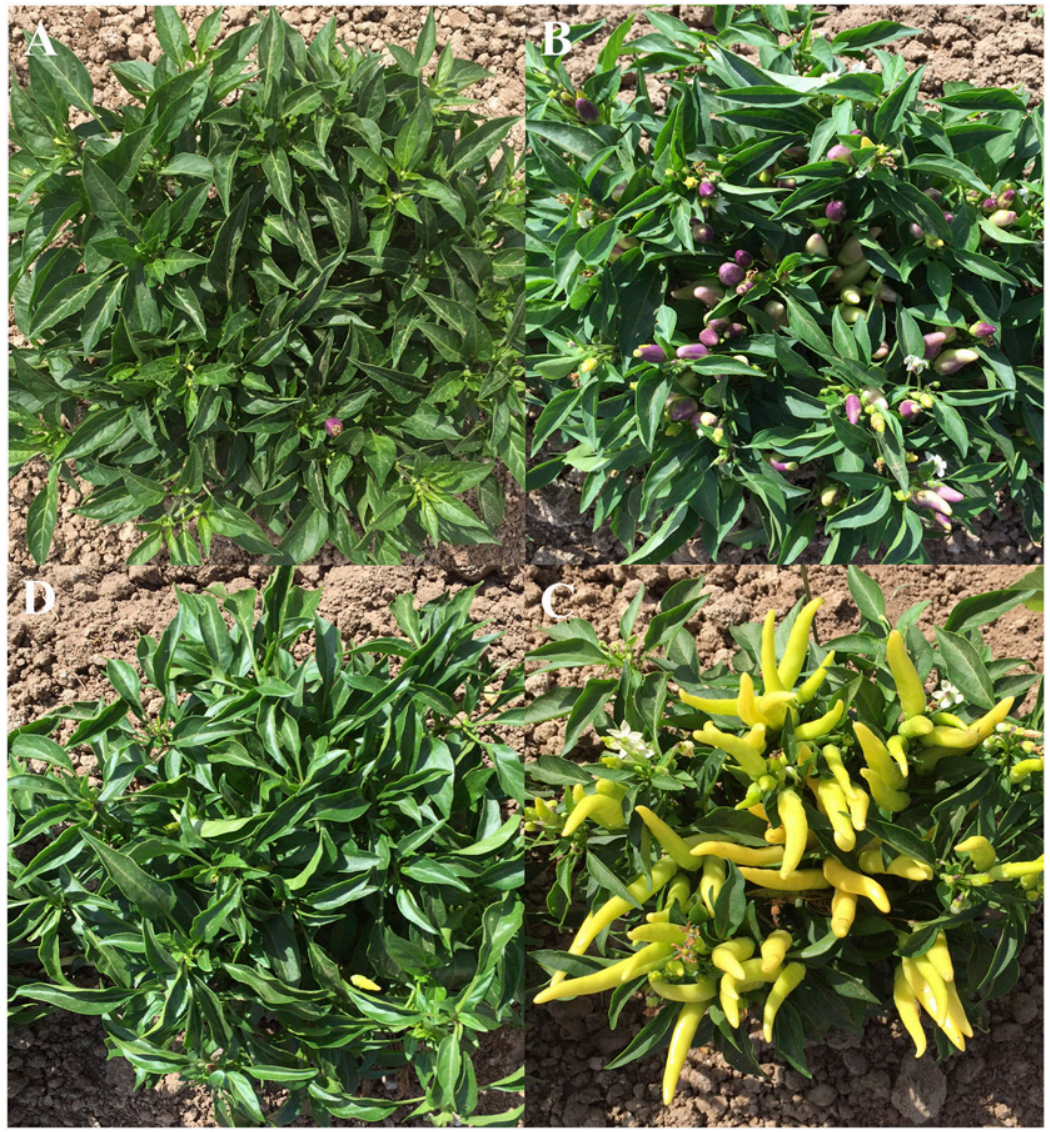

Fig. 4. Representative observable differences in chile pepper flower bud, open flower, and fruit number of (A) 2000-ppm-treated 'NuMex Easter', (B) 0-ppmtreated 'NuMex Easter', (C) 2000-ppm-treated 'Chilly Chili', and (D) 0-ppmtreated 'Chilly Chili' grown at Leyendecker Plant Science Research Center (La Mesa, NM) in 2015, $8 \mathrm{~d}$ after ethephon treatment; $1 \mathrm{ppm}=1 \mathrm{mg} \cdot \mathrm{L}^{-1}$.

should be considered when applying ethephon. Nevertheless, ethephon can be effective for efficient breeder seed production in chile pepper crops by reducing, although not entirely eliminating the need for manual open flower and fruit removal.

\section{Literature cited}

Bosland, P.W. 1993. An effective plant field cage to increase the production of genetically pure chile (Capsicum spp.) seed. HortScience 28:1053.

Bosland, P.W. 1999. Chile peppers, p. 17-21. In: B. Hanson (ed.). Encyclopedia of chiles. Hdbk. Ser., Brooklyn Bot. Garden, Brooklyn, NY.

Bosland, P.W. and S.J. Walker. 2004. Growing chiles in New Mexico. New Mexico State Univ. Coop. Ext. Serv. Guide H-230.
Cantliffe, D.J. and P. Goodwin. 1975. Red color enhancement of pepper fruits by multiple applications of ethephon. J. Amer. Soc. Hort. Sci. 100:153-157.

Davis, K., E. Stover, and F. Wirth. 2004. Economics of fruit thinning: A review focusing on apple and citrus. Hort Technology $14: 282-289$

Hayashi, T., R.D. Heins, A.C. Cameron, and W.H. Carlson. 2001. Ethephon influences flowering, height, and branching of several herbaceous perennials. Sci. Hort. 91:305-323.

Kahn, B.A., J.E. Motes, and N.O. Maness 1997. Use of ethephon as a controlled abscission agent on paprika pepper. HortScience 32:251-255.

Khademi, M. and M. Khosh-Khui. 1977. Effect of growth regulators on branching, flowering, and fruit development of ornamental peppers (Capsicum annuиm L.). J. Amer. Soc. Hort. Sci. 102:796798.
Krajayklang, M., A. Klieber, R.B.H. Wills, and P.R. Dry. 1999. Effects of ethephon on fruit yield, color and pungency of cayenne and paprika pepper. Austral. J. Expt. Agr. 39:81-86.

Lulai, E.C. and J.C. Suttle. 2004. The involvement of ethylene in woundinduced suberization of potato tuber (Solanum tuberosum L.): A critical assessment. Postharvest Biol. Technol. 34:105-112.

Rosales, R., M. Jamulena, P. Gómez, and D. Garrido. 2009. Hormonal control of floral abscission in zucchini squash (Cucurbita pepo). Plant Growth Regulat. 58:1-14.

Santos, R.M.C., M.F. Nascimento, N.F.F. Nascimento, A. Borém, F.L. Finger, D.S. Costa, E.R. Rêgo, and M.M. Rêgo. 2013. Ethylene resistance in a $F_{2}$ population of ornamental chili pepper (Capscium annuum). Acta Hort. 1000: 433-438

Stommel, J.R. and P.W. Bosland. 2006. Ornamental pepper, Capsicum annuum, p. 561-599. In: N.O. Anderson (ed.). Flower breeding and genetics: Issues, challenges, and opportunities for the 2 lst century. Springer, Dordrecht, The Netherlands.

Sun, Y., L.B. Stack, D. Zhang, and Z. Gu. 2011. Control growth of Euphorbia pulcherrima Willd. ex Klotzsch 'Sonora Jingle' and 'Sonora White' using ethephon. Hort. Envrion. Biotechnol. 52:351-356.

Tanksley, S.D. 1984. High rates of crosspollination in chile pepper. HortScience 19:580-582

Tripp, K.E. and H.C. Wien. 1989. Screening with ethephon for abscission resistance of flower buds in bell pepper. HortScience 24:655-657.

Uchanski, M.E. and A. Blalock. 2013. Ethephon improved pigmentation but had no effect on cayenne pepper fruit yield in southern New Mexico. HortScience 48:738-741.

Wang, X., R.A. Arancibia, J.L. Main, M.W. Shankle, and D.R. LaBonte. 2013. Preharvest foliar application of ethephon increase skin lignin/suberin content and resistance to skinning in sweet potato storage roots. HortScience 48:12701274 .

Weis, K.G., B.D. Webster, R. Goren, and G.C. Martin. 1991. Inflorescence abscission in olive: Anatomy and histochemistry in response to ethylene and ethephon. Bot. Gaz. 152:51-58. 